
in

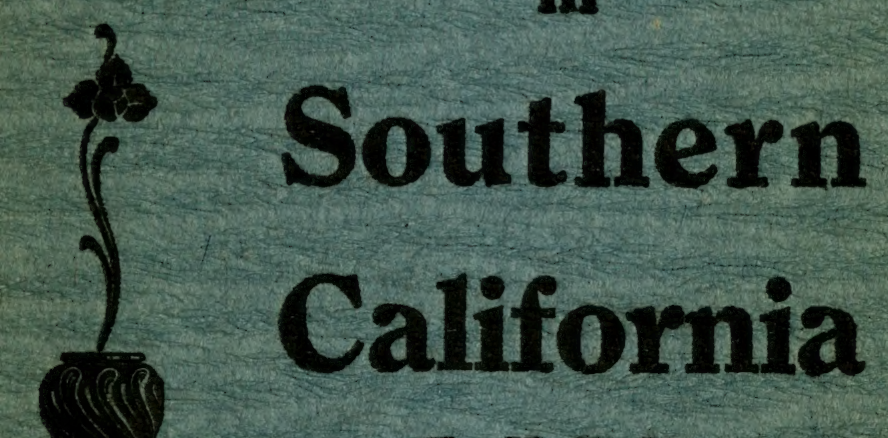
By H. E. Stes

Gardening 1 (5) 

Gardening

Soun

Southern California

\author{
BY \\ H. E. SIES \\ SAN DIEGO, CALIFORNIA
}

Price, 50 Cents 


\section{$5 B^{9^{5}}$}

Copyright 1918

By H. E. Sies, San Diego, California



(C) $C 1.4511145$ 


\section{Read This First}

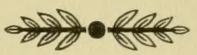

In Southern California, soil conditions are so varied, that there can be no set rule for its preparation any further than the use of decomposed vegetation, cow and horse manure will apply everywhere.

Most chemical fertilizers in time leave the soil in an impoverished condition.

The various fertilizers that will be mentioned in this booklet, are soil builders to a more or less degree.

Your own experience must determine the one or ones best suited for your use.

The writer will adhere strictly to the planting and growing conditions for Southern California, as they apply to city homes, and in compiling this booklet has only one aim and thought in mind. That is to endeavor to place before its readers in as plain and clear a manner as possible how to prepare the soil and succeed in the growing of those things the most universally sought for.

If he has succeeded in placing the subject matter in a way that the reader gets the full value out of it, he will feel that success has crowned his efforts.

By earnest and diligent application of knowledge acquired only do we succeed. So in the degree that you set yourself about the task of getting into harmony with nature and nature's ways and wonders, will you have the satisfaction of realizing to the fullest extent what a sublime builder of mind, body and character she is. 


\section{Calendar for Vegetable Garden}

\section{Sowing Seed and Planting Out Vegetables in Following Months}

\section{JANUARY AND FEBRUARY}

SOW-
Beets
Carrots
Early Cabbage
PLANT-

Kale
Lettuce
Onion
Parsnip
Potatoes

Peas

Radishes

Spinach

Turnip

Cabbage

\section{MARCH}

In addition to list for January and February add: sow-

Late Cabbage Sweet Corn Egg Plant PLANT-
Cucumber Musk Melon Squash

Cabbage
Tomatoes

Watermelon

Beans

Tomatoe

\section{APRIL}

Sow seed and plant same as for March with following additions:

Pepper plants and seed

Egg Plant and Seed

MAY

Sow seed same as for foregoing months.

PLANT-

Cabbage

SOW-

Beans

Beets

Cucumber

Sweet Corn

Egg Plant

PLANT-
Tomatoe

Sweet Potatoes

\section{Egg Plant}

JUNE

Lettuce

Musk Melon

Onion

Parsnip

Peas
Pepper

Pumpkin

Radish

Squash

Watermelon

Same as for May. 


\section{JULY}

sow-

Beans

Beets

Onion

Lettuce

Pumpkin

Radish

Summer Squash

PLANT-

Cabbage

Cauliflower

\section{AUGUST}

sow-

Beans

Beets

Early Cabbage

Cauliflower

Kale

Lettuce

Onion
Peas

Radish

Tomatoes *

*For winter crop in frostless sections.

PLANT-

Potatoes

SEPTEMBER

SOW-Same as for August with addition of Parsnips. PLANT-

Potatoes

OCTOBER

Same as for August with exception of omitting Tomatoes.

\section{NOVEMBER AND DECEMBER}

Same as for October.

You can sow every month in the year:

Beets

Carrots
Lettuce

Radish
Turnips

Plant Onion sets all year round. 


\section{Calendar for Flower Garden}

\section{Sowing Seed and Planting Out Flowers in the Following Months}

\section{JANUARY AND FEBRUARY}

SOW-

Alyssum

Calliopsis

Candytuft
Centaurea, or

Wall Flower

Cosmos

Gaillardia
Larkspur

Migonette

Poppies

Sweet Peas

\section{MARCH}

Sow same as above with following additions:
Aster
Dahlia
Zinnia

APRIL

Sow same as for preceeding months with following additions:

Morning Glory

Cypress Vine

Marigold
Shasta Daisy

Verbena

Wall Flower
Discontinue Sweet Peas

\section{MAY}

Sow same as for preceeding months.

PLANT-

Dahlia Bulbs

Aster

Chrysantheum

Zinnia
Pentstemon

Salvia Plants

\section{JUNE}

Discontinue seed-sowing.

Plant same as for May. 


\section{JULY}

Discontinue seed-sowing.

\section{AUGUST}

SOW-

Cineraria

Pansy

Stocks

Snap Dragon
Christmas flowering Sweet Peas

\section{SEPTEIMBER}

Sow same as for August with addition of Shasta Daisy.

\section{OCTOBER}

SOW-

"Pot Merigold"

Everlasting FlowersMigonett

Candytuft

Cosmos
California Poppy Larkspur

Winter Sweet Peas

Pansy

Plant all kinds of Bulbs.

Dutch Bulbs

Hyacinths
Narcissus

Jonquils
Stocks

Poppies

California Wild

NOVEMBER AND DECEMBER

Sow same as for October, including planting of Bulbs.

Etc., Etc.

Flowers 


\section{Roses}

Roses as a class do not thrive in a dry climate, therefore the list for San Diego is very limited,scarcely a dozen varieties in bush roses. In climbing roses, five or six varieties and you have the list of truly desirable climbers. But it is most gratifying to know that this limited number serves us well.

If I were putting in a private garden for myself, I would confine myself to the following list:

General McArthur White Cochet Frau Karl Druschki

\section{La Detroit}

Cecil Brunner
Kaiserine Augusta Victoria

Pink Cochet

Mm. Able Chatenay

Souver de Pierre Notting is the nearest yellow that I would give garden room to. Mrs. A. R. Waddell, a reddish apricot toned with salmon, and the new rose, Los Angeles.

This list with ordinary care will give good results.

Budded stock is much more desirable than those grown on their own roots, the bushes will be stronger and last four times as long. In climbers, the Climbing Cecil Brunner, Lamarque, Reve d'Or, Mme. A. Carriere, Dorothy Perkins, (the latter named being subject to mildew) and Thousand Beauties, would be my limit for climbers. White, pink and red Cherokees are extra good for hedges. Rose bushes will not do 
well in sandy soil. A heavy, loamy soil, well enriched with horse manue is the best. Where the soil is light and sandy use cow manure. Dig holes at least eighteen inches leep, and two feet across. Prepare the soil and treat in the same manner as for fruit trees. The amount of manure to be used being three shovelsful to each hole thoroughly mixed with the soil. Rose bushes should be spaced at least three feet apart. Where it is budded stock, plant the bud at least two inches under ground.

Your nurseryman will show you the bud and explain it to your. Also have him prune out any broken or mutilated roots. He should also prune back the roots and the top of the rose bush, removing all of the small twigs.

In planting, lay the roots in the hole in their natural position. fill in the dirt and press firmly around the bush with your foot, leave a space around your rose bush the same diameter as the hole, having a rim of dirt high enough to let the water run slowly to the depth of four inches, when the water has soaked into the ground, then draw the loose dirt into the depression. This mode of planting applies to trees, shrubs and vines. Weather conditions govern how often to irrigate.

When trees and shrubs have no leaves on them, they require but little moisture. The more leaves they have the more moisture they require. There is little danger of over watering rose bushes during the growing season, from spring to early fall in fact, the danger lies the other way-they do not get enough. I get my best results irrigating once a week. Do the irrigating in the forenoon, also wash off the foliage every three or four weeks. I am not in sympathy with resting rose bushes by withholding water from them during July and August, until they have been established in 
the ground at least two years. I have seen more rose bushes ruined and lost by withholding water from them than all causes put together, especially if the soil is not as heavy as it should be. You should try to arrange to do your planting of rose bushes during the months of January, February and the fore part of March. The nurserymen are usually prepared to furnish you rose stock at all times, having them in boxes and large cans, which are planted out at any time of the year, causing no harm to or setting back the bushes in their growth.

The pruning of rose bushes should be done during December and January. In the list of rose bushes that I have named, only the Frau Karl Druschki should have the main stocks trimmed back severely, as it makes a growth anywhere from six to twelve feet high, often being mistaken for a climber. It should be pruned back to within four or five feet of the ground. Prune off every side shoot there is on the main stalks, close up to the stalk, cut out all small or stunted stalks and the ends of the main stalks where they start to get small at the ends. Let the main stocks be absolutely stripped of every leaf or twig that has a leaf. Bear this fact in mind,--only the new growth that comes from the main stocks produces rose blooms.

In January or February proceed to fertilize with fresh horse manure if the soil is heavy, if sandy or light use cow manure, to a depth of four or five inches. (Do not guess it but measure.) The surface of the ground to be covered to be not less than two feet in all directions from the base of the bush and farther if your bushes are large and the root system extends farther. After the manure has laid four or five weeks and the winter rains have carried much of the strength from the fertilizer to the roots. spade or fork it all under. 
using care not to injure or tear the roots, working close to the surface of the ground, as you near the base of the bushes.

To employ the same system in pruning your climbing rose bushes would be nothing short of butchery and ruin for them. Those fine new long shoots that come out, getting in everybodys way and looking so out of place are the ones to be saved. In climbing rose bushes, the new growth of this year gives the great profusion of bloom next season. Save them by all means. Cut out as much as is necessary of the old part of the vine to give a place for the new growth. Climbing rose bushes that are planted where the root system reaches the lawn need no special care or attention after once getting established.

\section{क्णै। 10 Dahlias}

No flower has made such rapid strides and come into universal favor to as great a degree as the Dahlia has during the past few years. Especially is this true on the Pacific Coast where climatic conditions are ideal to its fullest development in size and beauty.

There is quite a list of varieties, the most of which the general public has as yet but little interest in. The three varieties that are in universal favor are: First, The cactus type, the petals being for the most part narrow and quilled.

The decorative type which has broader petals, on the order of large rose blooms. 
Then the Peony, or Art Dahlias as some are pleased to designate them. These as a rule are semi-double, petals are large, broad and often times irregular, which adds more than it takes from their beauty.

Dahlias will thrive in any kind of soil, providing they have proper care. They give the best results in sandy or loose soil that does not dry down hard after watering. The heavier the soil, the more work and fertilizer is required. Chemical action in heavy soils seems to take up fertilizer much more rapidly than in lighter soils.

In Southern California, Dahlias can be planted any time from March to July, coming into bloom in from six to eight weeks after planting. They do quite well in partial shade but full sunlight is best.

To get the best results they should not be planted closer than three fect in the row and four feet betwcen the rows. The ground should have a covering of either cow or horse manure at least three inches deep,- the same being worked into the ground to a depth of twelve inches. This should be done at least four or five weeks before planting time,--using care that none of the manure comes in contact with the Dahlia tuber when planting, as it may give them the scab, an infectious disease to be avoided. Do not stand the tuber on end, or plant in a vertical position but almost flat or horizontal with the neck or bud end a little higher. From the top of the tuber to the top of the ground when the tuber has been covered, it should be four inches, in other words, the tuber should be planted four inches deep, counting from the top of the tuber. Keep the ground moist but not wet until they begin to grow nicely. As they make stock and foliage, more moisture is required.

When the buds begin to mature, the irrigating, fertilizing and cultivating begin in earnest. After irri- 
gating do not let the ground dry out hard at any time from the time the tuber is put into the ground until you desire to have them stop blooming. In heavy soil. cultivation usually follows on the second day after watering. Use a three or five prong hand cultivator. Having planted your tubers four inches deep, you can safely cultivate to a depth of two inches.

When they commence to bloom, plant food is taken up very fast. Work in a teacupful of bone meal to each plant about once in every six or eight weeks. If you have chickens, make liquid manure from their droppings and apply after irrigating. You can add along with it a tablespoonful of domestic ammonia to each gallon of water or liquid. Apply from one to two quarts to each plant.

Liquid chicken, sheep or goat manure is very strong and must be well diluted. A receptacle filled onequarter full of manure and then filled with water, should be diluted four times more before applying. It should be made up 24 to 48 hours before applying.

I rely on the liquid sheep manure and the ammonia, once a week during the blooming season. I irrigate every five to six days. As soil conditions vary so, there cannot be any set rules in these things, each and every one having to work out these problems from their own experience and observations. If you do not care to cultivate the ground the entire season, you can, when the Dahlias begin to bloom, mulch with coarse horse manure using care to keep the manure at least two inches away from the Dahlia stock, as it would harbor aphis, which would soon destroy the plant. Dahlias can be grown to a very large size by dis-budding, only allowing a few blooms to the plant. In the summer time when the days are long. and there are no fogs it is of great benefit to the Dahlias to give them an overhead spraying in the morning before the 
sun gets hot. The water will not harm any of the bloom, except the white ones, which you must avoid getting wet. Do not do this in foggy weather, as it will induce mildew.

At the least sign of mildew, give a dusting of dry sulphur, which will check the mildew at once. By keeping the blooms cut off, and not allowing them to remain, with faithful care in the matter of fertilizing, water and cultivation, they can be kept blooming well into November, providing weather conditions remain favorable.

Do not withhold water from them altogether when the blooming season is past. Do not be in a hurry to have the tops die off. When the tops have dried off, do not cut them down close to the ground, but leave the main portion of the main stocks on until you go to divide the tubers in the spring. The stocks are hollow and if cut close to the ground, the water from the winter rains will run down this hollow place and often cause the base of the stock to rot away, sometimes being the cause of losing the entire clump. This treatment applies to a frostless climate.

Where they have frost and freezing weather, the Dahlias are taken up after the tops have been killed by the frost.- the tops cut back to ten inches above the ground. The Dahlias are left lying on the top of the ground for a day or so to dry off. Then put into a cellar or a similar place to protect them from freezing during the winter and replanted in the spring, when the ground has warmed up and all danger of frost is passed.

Where the soil is sandy and has good drainage, it is all right to leave them in the ground, hilling the soil around the stocks until near the first of March, but if the soil is the kind that packs down hard and 
holds water, then they must be taken up before the heavy rains begin.

Prepare a place where it is shady if possible, by digging down about four inches, take the Dahlias up with all the soil that will stick to them, set them in this place that you have prepared and put dirt all over them in such a manner that the water from the rains will drain away from them.

In our climate they need a little moisture all the time otherwise they dry out and are lost.

If you have never grown any Dahlias, you will do well to remember the following instructions, for unless you are informed as to how to divide your Dahlia tubers from the clump, you are going to ruin and lose the entire lot.

When you receive your Dahlia tubers from the grower in the spring, by looking closely you will see that the tuber has no sprouts coming out of it, but that it is connected by what is known as a neck to a piece of the base of the stock which grew up out of the ground and had the blooms on. Here is where the eye is or new sprouts come from that push up through the ground and make the new plants. All new growth comes out from the base of the old stock. The tubers are feeders, nothing more, and if broken off at the base of the stock to which they are attached, they produce nothing and are worthless.

Before dividing your Dahlia tubers it is best to wait until the buds begin to show up a little, then cut in so as to get one or two buds that will be attached to one or two tubers.

When you are ready to divide your Dahlias, do not shake the dirt or jar it from off your Dahlia clumps, but remove the dirt by gently digging out, or turn a 
strong stream of water on from the garden hose and wash the dirt out. It will be well to procure a keyhole saw. The blade is very narrow, and have it filed for a cut-off saw. The hardware dealer will explain. Saw off the old stock close down to the tubers, not below any buds. Then saw down through the center of the stock, which is in the center of the tubers. If there are a large number of tubers attached to the stock, you are going to lose some of them for there will not be enough of the stock to go around. After you have sawed through, then you can finish the job with a sharp, thin bladed knife,--something a little bit stronger than a potato knife, though a potato knife does very well. Make a clean cut right straight through with either saw or knife. Under no circumstances do any prying for that bruises the wood and causes it to decay.

The key-hole saw that I have referred to you will find to be one of the best instruments you ever had for a general purpose tool for getting into narrow places for pruning out shrubs, trees and vines. It far surpasses the best pruning saw I know of.

Notes: The best time to put stakes at your Dahlias is when you plant the tubers. Drive so they will be on the east side of the plant. As the stock grow up tie them with a soft, but strong twine (sacking twine is extra good). As the prevailing winds come from the West, it is more desirable to have the stakes on the East side, so that if the string for any reason should come apart, the plant will rest against the stake, as it would not do if the stake had been on the West side. I use the ordinary lath, sharpening off one end, they are inexpensive and satisfactory.

The best time to cut the bloom is in the cool of the morning, followed at once by boiling the tip ends of the stems for about three minutes, which greatly aids 
their keeping qualities. Dahlias cut right after an irrigation will keep but a short time, in fact not at all.

Growing Dahlias from seed. Very few are awarc that by planting dahlia seed in March they will be in full bloom by August.

By procuring seed from growers who save seed only from their best stock, makes it possible to get some very fine new varieties. It is highly fascinating and well worth the effort.

Seed from cheap and common stock is a sure waste of time and effort. Get the best and see how much pleasure you get out of it.

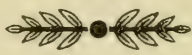 \\ Sweet Peas}

California has outstripped the world in the growing of sweet peas. In seed alone the growers have a market far exceeding a hundred tons a year.

The early or fast growing type known as the winter, or Christmas Sweet Peas, seem to give the best satisfaction.

You can plant as early as August but if the weather should be unusually dry or hot, they will make slow progress until the rains come. They like rich soil that is inclined to be firm. Where the soil is sandy and loose, work in rotted cow manure that has been spread on the ground four inches deep. 
As you sow sweet peas in rows, it is not necessary to fertilize over a large space. Twelve to sixteen inches wide is sufficient and whatever length the rows are going to be. They should have a sunny situation and the rows run north and south.

As previously stated, if the soil is of a loose sandy nature when ready for planting take a short piece of board,--say two feet long and press the soil down by standing on the board. Then let the water run slowly on the soil until it is thoroughly wet, after which sow the seed quite thick in the center of the row. Cover to a depth of about one inch and gently press down the soil. A covering of fine rotted manure to the depth of $1 / 2$-inch would be good and help retain the moisture. See that they are kept moist but not soaking wet. When the new shoots are coming through the ground, look out for insect pests. Do not wait until your sweet peas are up and laying over on the ground before fixing something for them to climb on. Do it at the time of planting.

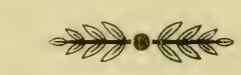

\section{Pansies}

A bed of these delightful and care dispelling plants with their inexhaustible supply of bright colored blooms is one of the most desirable to have for winter and spring flowers. Seed can be sown from August to January. Shallow boxes should be used not more than four inches deep. See that the box is not water tight, but that the water can drain through. Use good, 
rich soil consisting of about $1 / 3$ rotted manure, $1 / 3$ leaf mould and $1 / 3$ good garden soil. Press the dirt down in the box, then thoroughly soak with water. To press the soil down and make a nice smooth surface use a piece of board or something of that nature, then after the soil has taken all the water it will hold, sow your seed and cover with just enough fine leaf mould or sand so that you cannot see any trace of seed. Press down gently with your piece of board.

The water you have put in the soil will provicle all the necessary moisture for several days if you do not allow the sun and wind to dry them out. To avoid this condition cover with piece of light muslin, burlap or glass that has been white washed, (even dust sprinkled on the glass will do). Anything to subdue the hot rays of the sun and at the same time let some warmth on the soil.

Have the box raised off the ground so that insect pests cannot get at the seed or plants.

Under no circumstances allow the seed to dry out during its germinating period as it will be ruined. When the plants show six or eight leaves, plant out in beds in a sunny place, not shade, where the soil has had a top dressing of well-rotted manure at least three inches deep, well worked into the soil to a depth of six or seven inches. Sugar beet lime is fine to add to the soil, especially is it so in regard to heavy, sticky soil. It keeps it from getting sour and is a wonderful help in every way. It should be sprinkled on the soil about $1 / 2$ to 1 inch deep and also worked in. Lime should be used for all outdoor planting during the rainy season.

Pansy beds must have good drainage. Should be two or three inches higher than the walks around them. Set the plants about eight inches apart. Never allow them to suffer for water. Do not keep the soil 
soaked but moist. Cultivate the soil just deep enough to keep it from crusting after watering.

A mulch of rotted manure about an inch thick on the surface of the bed, will be highly beneficial.

The directions for sowing pansy seed in boxes will apply to all seeds that should be started in that manner, such as Aster, Dahlia, Pentstemon, Snap Dragon, Salvia, Zinnia, Shasta Daisy, Verbenia, etc.

When it becomes necessary to water these seed boxes, it is best to set the box in a tub with just enough water to come close to the top of the box, as it sets in the water, and let the soil in the box take it up from underneath instead of the top. Do not allow the water to come up above the surface of the soil in the box. Let this watering be done in the morning. When the seed begins to sprout, keep the cloth or glass at least ten inches above the box to allow a free circulation of air during the day.

As the plants grow let them have a little sunshine each day, increasing the length of time a little every day as the plans grow until they get where only partial protection is needed.

It is best to let the plants have the morning sun before the wind begins to blow.

In planting seed of any kind in the open ground, either vegetable or flower, if done during the dry season, the ground must be thoroughly soaked to the depth of 2 feet or more. Fertilizer thoroughly worked in, and soaked with water again as soon as it is dry enough to work up nicely. Sow the various seeds according to directions given on the seed packets, or by the dealer.

Spread sacking over the seed and keep moist by sprinkling water on the sacking. Remove the sack- 
ing as soon as the seed has sprouted up out of the ground.

This applies to dry weather planting. During the rainy season, when there is moisture in the air, the sacking can be dispensed with, unless the days should happen to be extra warm and dry.

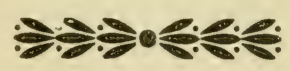

\section{Preparing the Soil and Planting of Fruit Trees}

Unless the soil is properly prepared in advance for the planting of trees and shrubs, for your flower and vegetable gardens, your efforts will come to naught. Soils that dry out hard after the rains or irrigations, should have a dressing of coarse horse manure, and for light, sandy soil cow manure to the depth of four to five inches. Turn under with a spading fork, then give a good soaking with water, when sufficiently dry so it works up nice and loose, give the ground another spading over. Then take a vineyard hook or a potatoe digger and proceed to pulverize the soil and mix in the manure. If the manure is fresh, which I prefer, planting should not follow under three or four weeks after putting the manure in the ground. If the manure is rotted before putting into the soil, planting can follow at once.

For fruit trees, holes as a rule should be dug at least three feet in diameter and three feet deep. A wheelbarrow load of manure dumped into the bottom of cach hole and another wheelbarrow load mixed into 
the soil that goes back into the hole is a good rule to go by.

Put the prepared soil back into the holes and thoroughly soak with water. This work should be done three or four weeks before tree planting time.

Where the planting is done in heavy soil plant all trees, shrubs and vines so that the water from the winter rains will drain away and not stand or settle around them, for you will lose them if this condition is allowed to prevail.

January and February are the best months to plant bare root stock, though the early part of March will do.

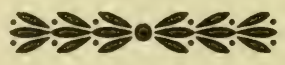

\section{Plant Pests and How to Get Rid of Them}

Ants: Here is where "a stitch in time saves nine." During the rainy season is a good time to locate and exterminate these pests, for the reason that the rains make it easy to locate them. Whenever a hill is located dig into it until you see the white eggs showing up. Have a kettle of boiling water at hand and pour it in.

If they get to working at the roots of plants, make up the following solution in any amount or proportion needed: Shave one pound of Fish Oil soap into one gallon of water. Add one pint of crude carbolic acid. Boil for about twenty-five minutes, using care not to let it boil over. Dilute this mixture at the ratio of 
one to twenty parts of water. Use freely around the roots. It can be poured into ant hills in place of hot water. It will not injure the plants.

Rose Beetle: Or known as Elephant bugs. They are a hard-shelled brown beetle, wingless, about $1 / 2$-inch long, with a raised back which gives them a slight appearance to an elephant. They will feed on almost anything that has leaves. Equal parts of sulphur and Paris Green dusted over the foliage makes a clean sweep of them. Arsenate of lead solution is also recommended. Use about two teaspoonsful of the powdered arsenate of lead to each gallon of water. Used as a spray.

House plants, especially ferns, often become infected with aphis and soft scales. A cube of toilet soap, one inch square, dissolved in one quart of water, used as a spray or dashed on with a whisp broom. Wash off with fresh water after twenty-four hours.

As to plant lice, or aphis, which infest the new growth of rose bushes, there are concentrated extracts of tobacco on the market that require only the proper dilution by water to make them available for use. "Black Leaf 40" has a high rating as a nicotine solution. This can be procured at any of the seed stores. Add in a little toilet soap, just enough to make the water show it a little.

Western Twelve-Spot Cucumber Beetle. Its color is a bright green with black spots. The State Horticultural Commission recommends Arsenate of Lead.

Slugs and Snails. Where the plants are young and tender, use four ounces of powdered Arsenate of Lead to ten gallons of water. (Arsenate of Lead is put up in two forms,- - paste and powdered.) The powdered is considered preferable. If the plants or foliage is strong and well developed, use six ounces to the same 
amonnt of water. This remedy applies to all leaf-eating pests.

Thrips. They are so small that they are classified as mites, and make their appearance in dry weather, working on the underside of the leaf, which become spotted and have a pale grayish color. The leaves finally drop off, leaving the plant or shrub bare. Spray the underside of the leaves with tobacco water. Also fertilize and water the plants freely. Fuchsias and Dahlias are especially subject to them.

Tree Tanglefoot. When a band of it is put around a tree. shrub or plant, no insect can pass it. One application will remain effective for three months in any kind of weather. Can be procured at any seed store. If spread on places where birds alight, they will leave and your seed beds will have a chance.

To keep birds out of fruit trees, run a pole up through the tree with a little perch nailed to the top of the pole, put insect tanglefoot on this perch; also put a little in places on the branches of the trees.

Mildew. Lose no time in dusting sulphur on the affected parts. It is one of the worst things we have to contend with on rose bushes. The best time to apply is early in the morning when the foliage is damp and there is no wind blowing.

Scab on potato or dahlia tubers. It is advisable before planting either potatoes or dahlia tubers to put them into a solution prepared as follows: Two fluid ounces of Formalin, being the same as one-eighth of a pint to four gallons of water. Immerse the uncut potatoes or dahlia tubers for two hours, take them out and dry off a little, then plant.

Sow Bugs or Slaters. This pest feeds upon germinating seerls, tender foliage, buds, fruits, many varities 
of roots and root crops. Raise any box, board or anything that they can get under, and you will find hundreds of them. I have seen them not wait for the seed of vegetables and flowers to sprout but go in the ground after it. Many persons have wondered why the seed never came up which they planted. In most cases, the reason can be traced to these pests.

Make a poison bait of the following, which will not only apply to Sow bugs, but to Slugs, Snails and Cut Worms also.

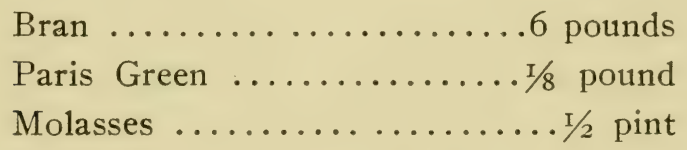

Thoroughly mix, adding sufficient water to make it moist but not sticky and scatter around where you find them the most numerous.

Scale on Orange, Lemon and Grapefruit trees. If your trees are infested with scale, consult the County Horticultural Commission, who will inspect the trees and inform you when and the best way to handle them.

Any disease making its appearance on trees, shrubs or plants, any insect pest that you do not recognize or know how to combat, lose no time to inform the Horticultural Commissioner about it. 


\section{Odds and Ends}

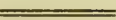

If you keep chickens or rabbits, when dressing them do not waste the blood, but save it, add about thirty times as much water and pour liberally about once a month into your hanging baskets, potted ferns, begonias, etc. It works wonders with all plants in the open ground as well.

A little bone meal sprinkled into the potted plants and scratched into the soil in the spring time is extra good.

A tablespoonful of domestic ammonia to a gallon of water is good for plants of all kinds. Use liberally right after watering.

Asparagus Springeri in hanging baskets or in pots after a season or so crowd themselves out so that it is advisable to pry them out, take a hatchet and cut away a large portion of the outside of the root system. and replant in new soil in which bone meal at a ratio of a handful to a bucketful of soil has been thoroughly mixed. This should be done in the early spring time. Any good fertilizer will do, if bone meal is not at hand.

Under no circumstances plant Eucalyptus trees on a city lot. Nothing else can grow under or near them. 
Fig trees have no tap roots, but have many little fiberous roots that work close to the surface of the ground. Never allow the ground to dry out from the spring time until the crop has been gathered.

During the winter time put on some fertilizer and spade under. A good thing to do to all of your trees. This should be done as far out, if not farther, than the spread of the branches.

Do not leave horse or cow manure out in an exposed condition to the wind and sun for any length of time as it will deteriorate very rapidly.

Fertilizers of any kind after being incorporated into the soil, three or four months have lost the major portion of their fertilizing value through chemical action, especially is this so of horse and cow manure. Fast growing plants take up fertilizer very rapidly.

One of the best habits to acquire is never attempt to sow or plant anything without first fertilizing the soil, which does not mean to throw it on the ground in any old way, but work it into the ground thoroughly.

Orange and Grapefruit trees often when young and just coming into bearing will drop their fruit, just after it is nicely started. This is invariably caused by over-watering. Never water citrus trees until the ground becomes dry, not only on top but ten or twelve inches deep.

Lawns if not faithfully cared for are soon crowded out by other growths that are in no wise desirable. Early in the spring I prefer a good commercial fertilizer, of which there are several on the market. Then in June a dressing of sifted cow manure is extra good, though you run the risk of introducing weed pests that you cannot get rid of easily. 
Some lawns pack down so hard that jabbing a spading fork in the lawn when moist and prying a little loosens the soil so that water and air get down into the ground better.

Lime water should be given all potted plants at least once a month. It sweetens the soil and destroys injurious insects that may be in the soil. This also applies to plants, shrubs, etc., in the open ground. It is easily prepared by filling an old keg, tub, bucket or any thing suitable about one-fifth or sixth full of lime and filling up with water, letting it stand for two or three days before using.

Hydrangeas when they begin to push out their new growth in the spring time should have a heavy fertilizing of some kind, it means large blooms.

When you wish the color of the blooms to be purple, bury some pieces of old iron around the roots.

Do not waste the grass from the lawn, weeds, leaves from shrubs or trees, vegetable tops, everything of this nature should be dumped into a hole in an out of the way place and kept wet. In the Spring time you will find the finest leaf mould for your ferns, begonias, and seed boxes. Do not dump the dish water into the sink but pour it around your rose bushes, trees, shrubs and flowering plants. Do not do it when things are not in need of moisture.

Bury the garbage around in the garden, it is needed there.

In sowing fine seed in shallow boxes or open ground it is important that in covering the seed the soil should be fine and evenly spread on. This is highly important. And a good way to do is to get a small, shallow box,-something you can easily hold in one hand. 
Knock the bottom out of it and put window screen on in place. This enables you to dust it on all right. These boxes can be had from your grocer.

The hole in which you dump your grass, weeds, leaves, etc., owing to the moisture will be a favorite place for snails, slugs, sow bugs and other garden pests, in fact it will be headquarters for them.

An excellent opportunity for you to make way with them by the use of the insecticides mentioned elsewhere.

Sprinkling should be resorted to for lawns, seed beds, ferns and begonias. Ferns and begonias grow their roots near the surface and should have a mulching of leaf mould two inches deep every spring.

With all deep rooting plants, trees and shrubs, sprinkling should never be resorted to except to wash off the foliage once in three or four weeks. The hose should be laid on the ground and the water run slowly until the soil has taken all it will absorb. Then don't forget to cultivate.

Coprosma, a shiny leaf shrub so extensively used in front of residences, should have the tip ends of the new growth kept pinched off. It makes the growth compact and keeps it from growing coarse and unsightly.

There is but one way to find out when trees, plants and shrubs need water. Go around with the hoe every day or so and dig down three or four inches.

Eternal vigilance in fertilizing, irrigating and cultivating during the growing and dry time of the yeat spell success. Don't forget it. 
Blood meal is extra good for flowering plants of all kinds. It gives a beantiful rich green to the foliage. and adds to the color and beauty of the blooms.

For a Dahlia that is budding for bloom, sprinkle a handful on the surface of the ground around the plant as far out as the roots go and stir into the soil.

The same amount for rose bushes and other plants according to their size. Repeat as their needs may indicate.

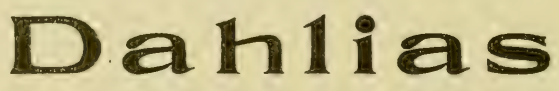

No expense has been spared to assemble one of the finest and most up - to - date Blue Ribbon collection of Dahlias in the United States. : : : :

A look through my 1919 catalogue, which will be mailed to any address on application, will convince you : : :

SIES DAHLIA GARDENS

3378 Granada Street, - San Diego, California Phone, Hillcrest 2020. H. E. Sies, Proprietor 


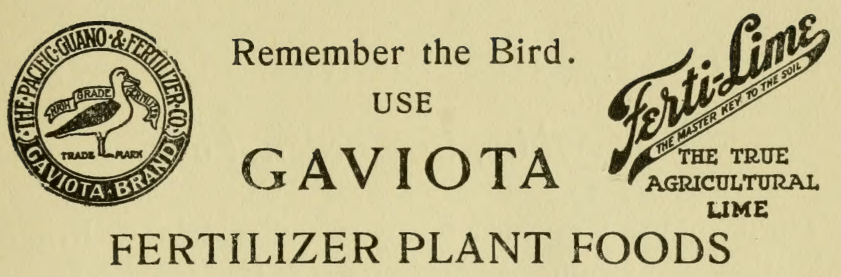

Prepared by Specialists for Your Particular Needs Produces Beautiful Roses, Flowers and Lawns

-Let us Advise and Help You-

The Pacific Guano \& Fertilizer Co. Both Phones
2127 Manure Fertilizers Sales Agent 511-533 7th St., San Diego Lime
ROBT. H. WINN

\section{Get Seeds That Grow FROM \\ SELEY'S SEED STORE}

644 E Street : : : Between 6th and 7 th

Roses, Palms and Ornamental Plants

Pacific Phone Hill. 350-W-1

\section{Mission Valley Nursery}

E. BENARD, Proprietor

R. F. D. No. 2

Box 156
Mission Valley San Diego, Cal. 
Pierce-Field Hardware Co., Inc. Everything in Garden Tools

The Famous Vineyard Hook, Garden Plows, Irrigation Apparatus, Wheelbarrows, Rubber Hose of the $\frac{5}{8}$ size, the happy medium in hose.

\section{A. B. CHRISTOPHER}

2928 29th St. COW MANURE DIRT AND SAND

Hillcrest 1298

Also put in Lawns and Landscape Gardening

\section{J. W. GROVE}

3216 TEAMING OF ALL KINDS Phone

I Street HORSE MANURE AND DIRT Main 1703

\section{S. A. HEMPHILL 4021 32d Street}

GENERAL GARDENING, HORSE and COW MANURE Putting in New Lawns a Specialty

\section{R. E. KERR}

2176 HORSE AND COW MANURE

Franklin St. Pine Shavings and Saw Dust
Main 5683-R

\section{J. F. RICKEY}

COW MANURE FOR SALE DAIRY

Telephone, Hillcrest 315-W-2

\section{T. B. PENICK}

Phones

3075 L St. HORSE AND COW MANURE Main 4582 GRAVEL, SAND AND SOIL Home 1488 


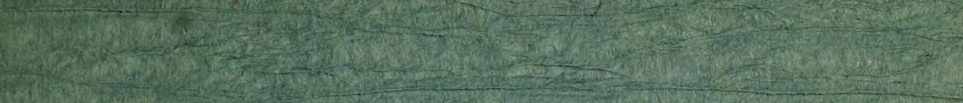

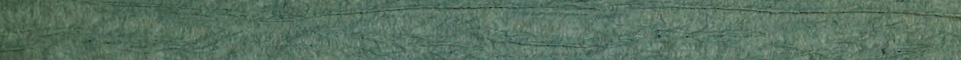

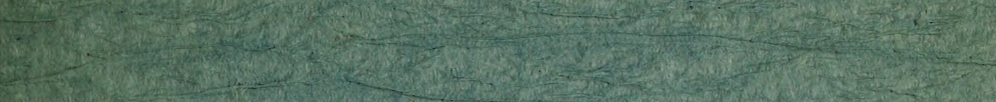

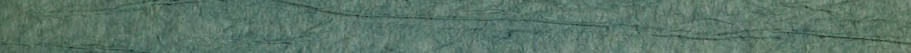



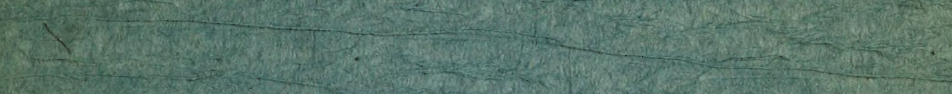

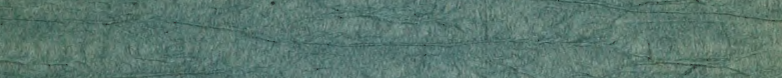

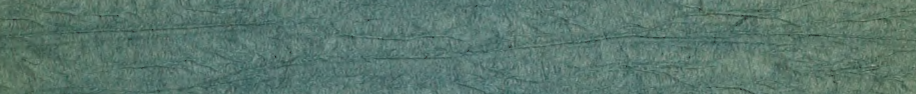
S.

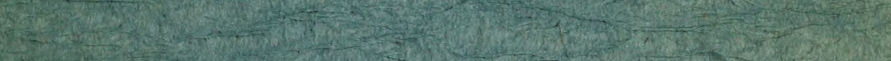



$$
\text { (1) }
$$
(2)

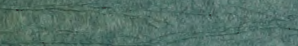
3.

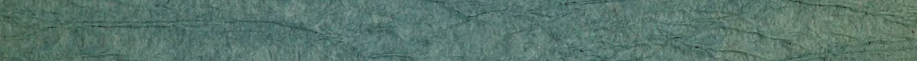
(3) W. (2) 60 (3)

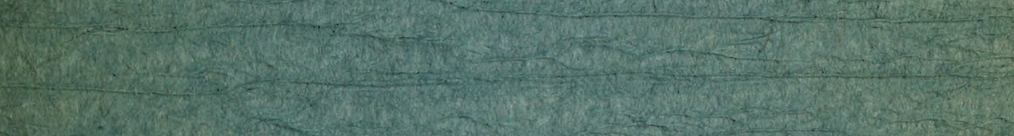
s. $x=$

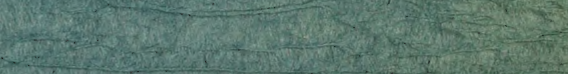
W

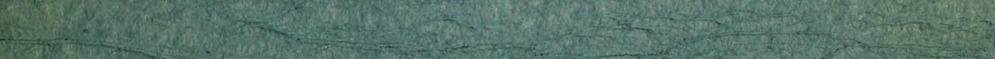

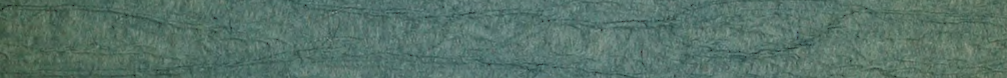

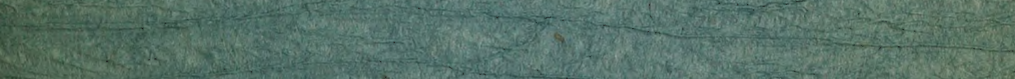

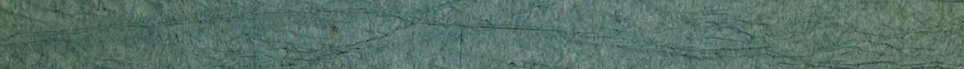

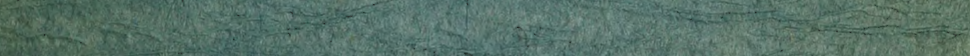



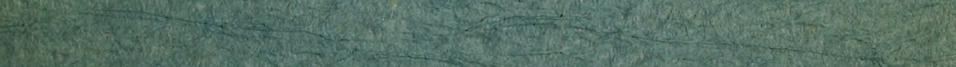

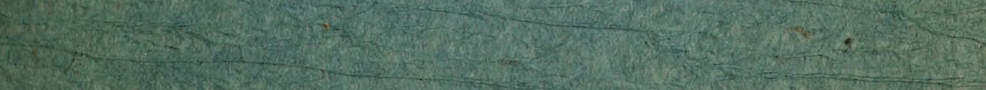

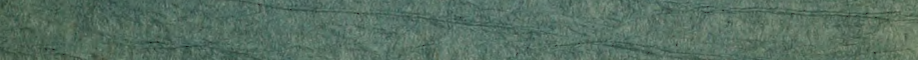
(3)

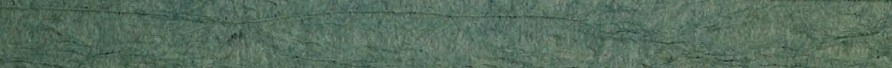
S.T. 


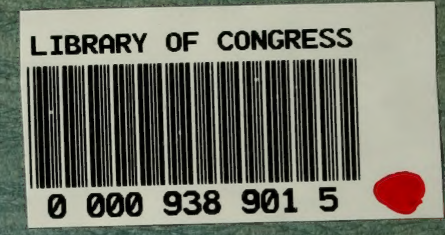

